\title{
Comparative Anatomical Description of Forearm and Hand Arteries of Cebus libidinosus
}

\author{
Descripción Anatómica Comparativa de las Arterias del Antebrazo \\ y de la Mano del Cebus libidinosus
}

*,**Tales Alexandre Aversi-Ferreira

\begin{abstract}
AVERSI-FERREIRA, T. A. Comparative anatomical description of forearm and hand arteries of Cebus libidinosus. Int. J. Morphol., 27(1):219-226, 2009.

SUMMARY: Recent data justify the insertion of Cebus on behavioral and evolutionary studies in relation to the human specie, reason why researches on behavior, memory, use of tools and encephalic index demonstrate that Cebus and chimpanzees are similar. Comparative anatomical studies between Cebus and chimpanzees based on anatomical data corroborate these data on evolutionary convergence associated to muscles, nerves and vessels of the thoracic members; however, the anatomy of the forearm and hand vessels has not yet been investigated in last years. The forearm and hand arteries of Cebus are identical to other here studied primates; however, the palmaris arch, which is only one in Cebus and baboons, and princeps pollicis artery, which originated from the palmaris arch, are the main differences found for the arterial model of Cebus and for other primates. The vascularization model is identical to others primates and humans, but the hand vessels are different and more similar to baboons.
\end{abstract}

KEY WORDS: Anatomy; Capuchin monkey; Cebus; Arteries; Forearm.

\section{INTRODUCTION}

Many studies on Cebus libidinosus (Rylands et al., 2000) were aimed at the anatomy (Aversi-Ferreira et al., 2005a, 2005b; Aversi-Ferreira et al., 2006; Aversi-Ferreira et al., 2007a, 2007b; Ferreira \& Prada, 2001; Neto \& Ferreira, 2002; Oliveira et al., 2000; Santini, 1983; Silva \& Ferreira, 2002; Silva \& Ferreira, 2003), cortical physiology (Lima et al., 2003), behavior and use of tools (Antinucci \& Visalberghi, 1986; Auricchio, 1995; Breseida \& Ottoni, 2001; Costello \& Fragaszi, 1988; Garber, 1987; Lopes, 2004; Resende \& Ottoni, 2002; Waga et al., 2006; Westergaard \& Fragaszi, 1987), encephalic index (Paiva, 1998) and memory (Tavares \& Tomaz, 2002), mainly because they present high cognition capacity and biological aspects that make them similar to Old World primates in relation to the use of tool (Mendes et al., 2000; Ottoni et al., 2001; Waga et al.), social organization capacity based on information transmission and learning on their behavior (Resende et al., 2003).

The great hand ability of Cebus was and still has been extensively studied (Ottoni et al.; Perondi et al., 1995;
Visalberghi et al., 1995; Waga et al.; Westergaard \& Fragaszi). The hand ability of big primates is used as evolution model to understand the use of tools by hominids (Toth et al., 1993); however, the behavioral abilities on the use of tools and cognitive capacity of Cebus (ChevalierSkolnikoff, 1989) justify the insertion of this primate on behavioral and evolutionary studies in relation to the human specie.

Indeed, researches on behavior, memory, use of tools and encephalic index demonstrate that Cebus and chimpanzees are similar and comparative anatomical studies between Cebus and chimpanzees corroborates these evolutionary convergence data (Aversi-Ferreira et al., 2005a, 2005b, 2006, 2007a, 2007b) associated to muscles, nerves and vessels of thoracic members. However, the anatomy of the forearm and hand vessels has not yet been investigated in last years, but any ancient papers (Manners-Smith, 1910a, 1910b) have cited study of the arteries of Cebidae in gene-

\footnotetext{
* Neurosciences and Behaviour Primates Laboratory (NECOP) - Federal University of Goiás - Goiânia - GO - Brazil.

*** Institute Atlas of Science and Technology (IACT) - Anápolis - GO - Brazil.
} 
ral, form. Aversi-Ferreira et al. (2007b) have studied the shoulder and arm arteries of Cebus and related interesting organization of these structures that present differences in relationship to humans, chimpanzees and baboons, and these data were explained because of differences in behavioral of locomotion, and before this paper the various studies about cognitive aspects of Cebus are been done without an anatomic basis to explanation of the important aspects like tool use, cognition and great hand ability of Cebus.

The vessels are the more variables structures of body (Manners-Smith, 1910a, 1910b), but the general model can be determinate.

The objective of this work is to study the forearm and hand vessels of Cebus genus and to compare the results with data from literature in relation to the same structures in humans, chimpanzees and baboons. These data will provide morphological differences and similarities between Cebus, Old World primates and humans, contributing for possible correlations on evolutionary, philogenetic and behavioral aspects between these species with anatomic basis.

\section{MATERIAL AND METHOD}

Samples. In this work, ten specimens of adult and healthy Cebus libidinosus (capuchin monkey) at different ages were used as follows: eight males and two females from one to three $\mathrm{kg}$ of body weight, black hair and with various brown hue, more commonly dark brown. The animals were donated by the Brazilian Institute of the Environment (IBAMA) from Sete Lagoas, state of Minas Gerais, Brazil in the year of 1970. The animals were deposited in the anatomical collection from the Uberlândia and Goiás Federal Universities. This work was previously approved by the UFG ethics committee (Veterinary Medicine).

Preparation of animals to dissection. Some dead animals were rasped with steel. The animals received latex 601-A (Dupot) mixed with red colorant diluted in ammonium hydroxide solution injected on the abdominal portion of the aorta; included in water at room temperature for 10-12 hours and $10 \%$ formaldehyde mixed with $5 \%$ glycerin through femoral vein perfusion for fixation. The animals were conserved on $10 \%$ formaldehyde, in closed opaque box.

Dissection and documentation. The forearm and hand dissection was performed with emphasis on vessels and documented with digital camera (Sony, 4.1 megapixels). The vessels denomination was based on the human and other primates' description in the human body Anatomy of Gray (Gray, 1918). The colleted data were analyzed and compared with models described for humans.

\section{RESULTS}

The dissection and description of arteries that irrigate the forearm and hand of Cebus monkey began from the elbow articulation, on the medial epicondyle, where the ulnar and radial arteries emerge in the forearm on the elbow cavity (fossa).

The radial artery presents smaller diameter and superficial position in relation to the ulnar artery that, by the way, follow distally and laterally by forearm to carpus articulation. The ulnar artery presents larger diameter and remains inner in relation to the radial artery.

After cross epicondilar foramen, the ulnar artery emerge in the forearm joining to median nerve and both emerges to medial face of forearm and follow to carpus articulation.

\section{Arteries: Individual description. Forearm arteries}

Anterior interosseous artery. The anterior interosseous artery (Fig. 1) arising from common interosseous artery (interosseous' trunk) that is a little trunk from ulnar artery. After its emergence on the forearm, the anterior interosseous artery has a little trajectory to the inner of the forearm to anterior face of the interosseous membrane, together with the anterior interosseous nerve, both are lateral to flexor digitorum profundus muscle and projects little branches to this muscle.

Posterior interosseous artery. The posterior interosseous artery arises by common trunk joining the anterior interosseous artery. After your origin this artery cross to posterior compartment of forearm and emerge bellow of the abductor pollicis longus muscle, is accompanied by posterior interosseous nerve, and take distal trajectory covered by extensor digitorum muscle. In 14 cases (70\%) this artery follows to carpus in order to help to originate the palmaris arch and anatomosis with the carpal dorsal artery. In the other four cases, this artery ends in the forearm.

Common interosseous artery. The common interosseous artery (Fig. 1) that generates the anterior and posterior arteries was found in all dissected animals. This little arterial trunk is originated from the ulnar artery after this vessel crosses the elbow fossa. 


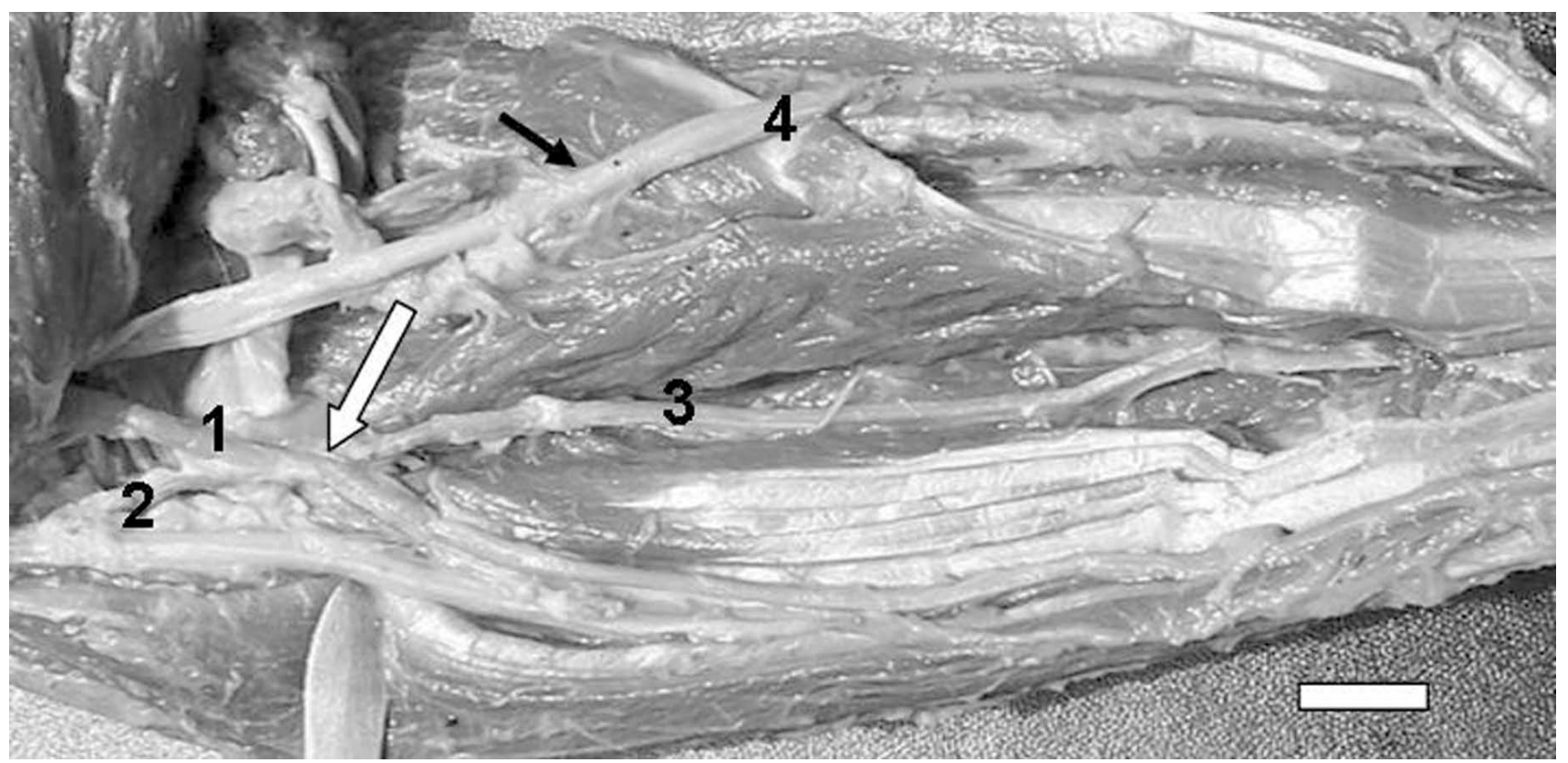

Fig. 1. Photograph of the anterior view of the Cebus left forearm. (1) Ulnar artery; (2) Recurrent ulnar artery; (3) Interosseous anterior artery; (4) Radial artery. The black arrow is evidencing the radial nerve and the white arrow is evidencing the interosseous communis artery. bar=1cm.

Radial artery. The radial artery (Fig. 1) after crossing the elbow fossa reaches the forearm and takes the distal and lateral trajectory, on the entire forearm lateral surface, crossing the flexor retinaculum up to the carpus. Along the entire trajectory, this artery was covered by the brachioradialis muscle, which in turn receives only a few branches from the radial artery. In the 14 casesstudied $(70 \%)$, seven from each side, this artery was positioned on lateral side to radial nerve by whole trajectory forearm one. In the distal portion, the radial artery is found at the medial position on the radial nerve. In all cases analyzed, the radial artery was positioned laterally in relation to the tendon of the flexor carpi radialis muscle and originated the carpal dorsal artery.

Radial recurrent artery. In all cases studied, only one radial recurrent artery originated from the radial artery was found. In the twenty forearms analyzed, this artery appear near to the radial artery in the forearm, and after take inner trajectory until to arterial net of the elbow articulation and take part of this net.

Ulnar recurrent artery. The ulnar recurrent artery (Fig. 1) was found in 14 cases analyzed (70\%), seven in each side, but in the other forearms, this vessel was not observed. This artery begins at the posterior portion of the ulnar artery yet in the forearm and takes trajectory transversally to the medial forearm surface, and ends in the anastomose with the inferior ulnar collateral artery, helping to construct the arterial net of the elbow articulation.

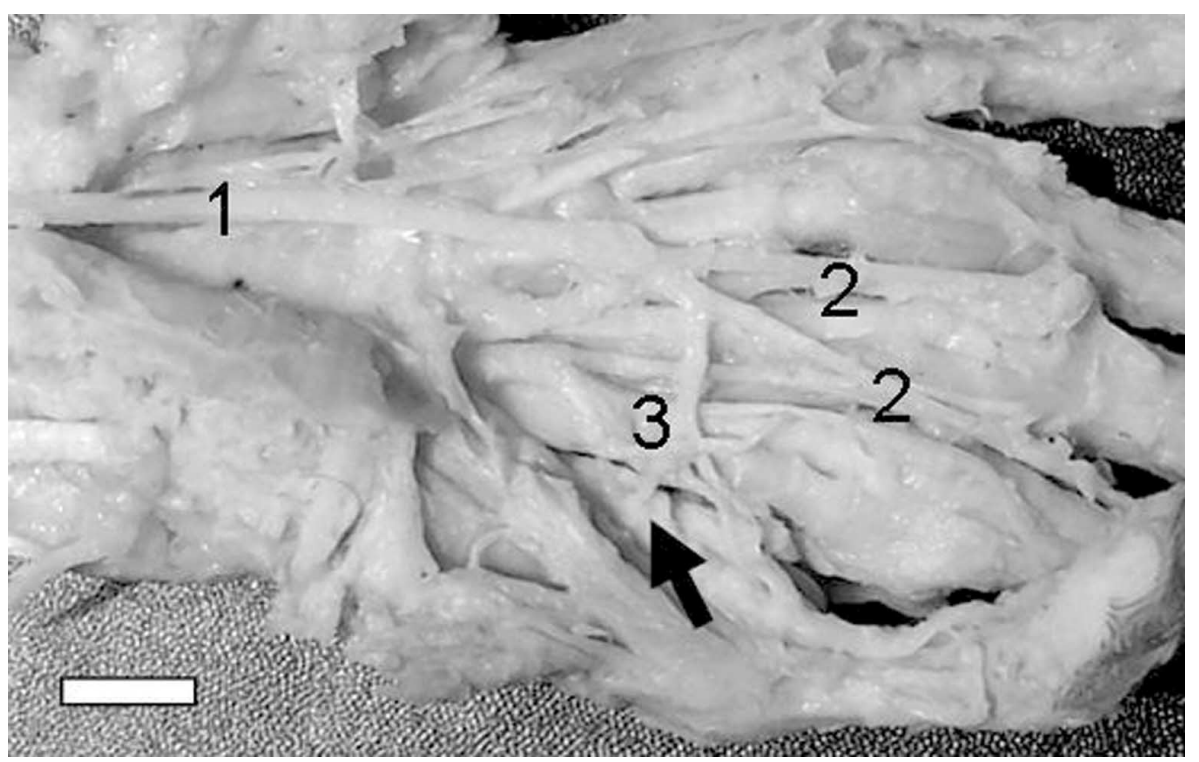

Fig. 2. Palmar view of the Cebus hand (1) ulnar artery; (2) digitorum communis arteries; (3) palmaris arch. The black arrow is evidencing the princeps pollicis artery origin by palmaris arch. Bar= $1 \mathrm{~cm}$ 


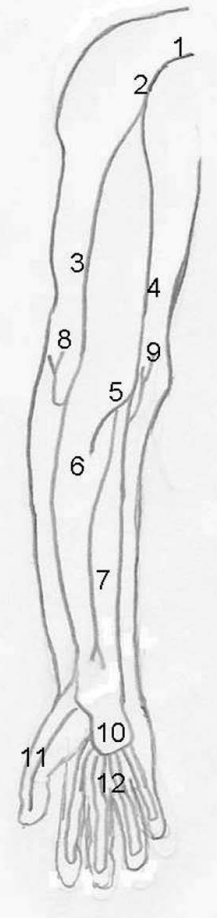

Cebus

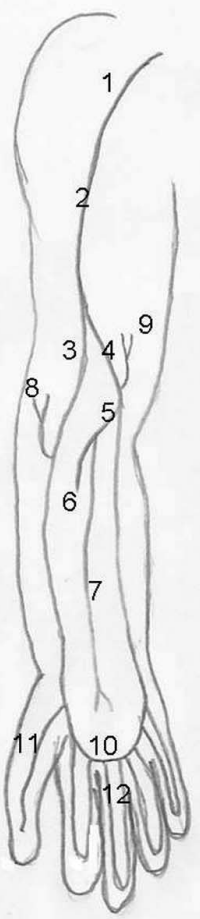

Baboon

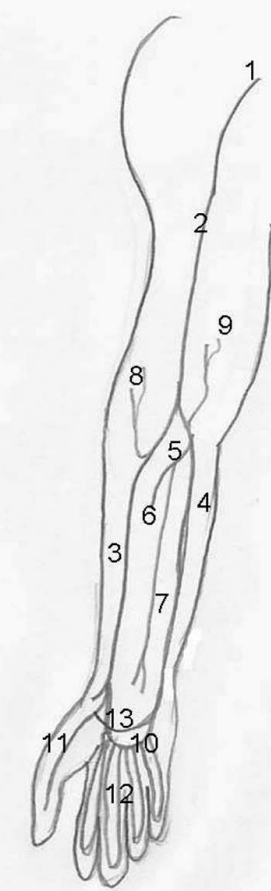

Chimpanzee and human
Fig. 3. Comparative scheme of the arterial model between Cebus, baboon, chimpanzee and human. (1) axillary artery; (2) brachialis artery; (3) radial artery; (4) ulnar artery; (5) interosseous comunis artery; (6) interosseous posterior artery; (7) interosseous anterior artery; (8) recurrent radial artery; (9) recurrent ulnar artery; (10) palmaris superficial arch; (11) princeps pollicis artery; (12) digitorum arteries; (13) palmaris profundus arch. Baboon, chimpanzee and human schemes are based on Swindler \& Wood (1973).
Ulnar artery. In the 18 cases (90\%), nine from each side, the ulnar artery (Figs. 1 and 2) reaches the forearm by crossing the epicondilar foramen of the humerus to accompany the median nerve, and separates from this nerve after the passage by the elbow fossa and joining by same fascia together to ulnar nerve. In the other cases ( 2 antimeres), the ulnar artery and the median nerve do not cross the epicondilar foramen of the humerus, but penetrate in the elbow fossa. The ulnar artery, after crossing the elbow fossa, reaches the medial face of the forearm and follows distally to the carpus, penetrating into the flexor retinaculum, situating medially to the tendon of the flexor carpi ulnar muscle.

Through its entire trajectory in the forearm, this artery crosses the flexor digitorum profundus muscle, which was also covered by flexor carpi radialis, flexor digitorum superficial and palmaris longus muscles at the proximal portion of the forearm, but at the end of the trajectory, it was covered by the flexor carpi ulnar muscle. In $80 \%$ of cases, from each side, the ulnar artery was laterally positioned in relation to the ulnar nerve, but in the other cases, this artery was medially positioned in relation to the ulnar nerve at the proximal portion of the forearm, but at the distal portion of the forearm, the ulnar artery crosses the ulnar nerve and remains at this position up to the carpus. The ulnar artery origin the palmaris arch.
Hand arteries. Many branches of the ulnar and radial arteries that irrigate the entire hand were identified in $100 \%$ of the cases studied. The ulnar artery originates branches to the palmaris brevis and hypotenar muscles and originates deep branches to irrigate the dorsal interosseous muscles. The (1) palmaris arch (Fig. 2) is only one in Cebus and is constructed through the superficial branch of the ulnar artery with little or absence contribution from the radial artery. The palmaris arch form the (2) princeps pollicis artery (Fig. 2). The (3) digitorum palmaris arteries (Fig. 2 ), princeps pollicis artery and the branch that reaches the flexor brevis pollicis are the terminal branches of the palmaris arch. The (4) carpal dorsal artery is originated from the radial artery.

\section{DISCUSSION}

Variations on the vascular system of baboons and chimpanzees are well documented (Swindler \& Wood, 1973) therefore, only a general model will be described here; however, the mainly differences will be evidenced.

The interosseous arteries, radial and ulnar recurrent arteries, digitorium palmaris arteries and carpal dorsal artery 
AVERSI-FERREIRA, T. A. Comparative anatomical description of forearm and hand arteries of Cebus libidinosus. Int. J. Morphol., 27(1):219-226, 2009.

Table I: Arteries of forearm and hand. Origin and similarities with others primates and humans.

\begin{tabular}{lll}
\hline \multicolumn{1}{c}{ Arteries } & \multicolumn{1}{c}{ Origin } & \multicolumn{1}{c}{ Similarities } \\
Anterior interosseous artery & Interosseous trunk (interosseous communis artery) & Humans, baboons and chimpanzees \\
Posterior interosseous artery & Interosseous trunk (interosseous communis artery) & Humans, baboons and chimpanzees \\
Interosseous communis artery & Ulnar artery & $\begin{array}{l}\text { Humans, baboons and chimpanzees } \\
\text { (subject many variations) }\end{array}$ \\
Radial artery & Axillary artery or brachial artery when present & Chimpanzees and humans \\
Radial recurrent artery & Radial artery & Humans, baboons and chimpanzees \\
Ulnar recurrent artery & Ulnar artery & Humans, baboons and chimpanzees \\
Ulnar artery & Axillary artery or brachial artery when present & Chimpanzees and humans \\
Palmaris arch & Ulnar artery & Baboons \\
Princeps pollicis artery & Ulnar artery & Different from other primates studied \\
Digitorum palmaris arteries & Palmaris arch & Humans, baboons and chimpanzees \\
Carpal dorsal artery & Radial artery & Humans, baboons and chimpanzees \\
\hline
\end{tabular}

have the same distribution for chimpanzees and baboons (Swindler \& Wood; Manners-Smith, 1910a), humans (Gray; Moore \& Dalley, 2001; O’Rahily, 1985; Spence, 1991; Testut \& Latarjet, 1959), and Cebus (Fig. 3). The MannersSmith (1910a, 1910b) not cite that the posterior interosseous artery too form the palmaris arch.

The ulnar and radial arteries in Cebus are divided near to the axilla, but this fact does not seem to influence the forearm arteries distribution (Aversi-Ferreira et al., 2007a). Aversi-Ferreira and colleagues (2007a) cited that the brachial artery was absent or was little in Cebus, but Manners-Smith (1910a) cited that there are two brachial arteries; meanwhile this is a words question, because the descriptions are the same to same type of arteries.

The radial and ulnar arteries in Cebus have the same distribution on the forearm of chimpanzees (Swindler \& Wood) and humans (Gray; Moore \& Dalley; O'Rahily; Spence; Testut \& Latarjet). Is very interesting noting that the palmaris arch in Cebus is identical to baboons (Fig. 3); however, the princeps pollicis artery is not identical to none of the primates studied here, because it is originated from the palmaris arch, that is derivate from ulnar artery; however, this vessel is originated from the radial artery for others primates studied here (Swindler \& Wood) (Table I, Fig. 3). Manners-Smith (1910a) cite that the ulnar artery to origin the palmaris arch superficial in Cebus and that this last origin the digital branches, include the pollicis branches, hence, do not denominated one principal poliicis artery, but us follow the text book to human description that is correspondent to existence of principal pollicis artery to Cebus.
The palmaris arch is only one in Cebus like baboons and is originated from of the ulnar artery with little contribution from the radial artery, with the same distribution as in baboons, and different from chimpanzees (Swindler \& Wood) and humans that have two superficial and deep palmaris arch (Gray; Moore \& Dalley; O'Rahily; Spence; Testut \& Latarjet). The palmaris arch in baboons and Cebus have correspondence with superficial palmaris arch in humans and chimpanzees. The ulnar artery form the palmaris arch on Cebus that continue as princeps pollicis artery, but in humans (Gray; Moore \& Dalley; O'Rahily; Spence; Testut \& Latarjet) and chimpanzees (Swindler \& Wood; Manners-Smith, 1910b) this artery is formed by direct branches of the radial artery.

In general, the non-specific arterial distribution of the forearm and hand in Cebus is identical to other primates, but specific and individual analyses revealed some differences, mainly in relation to the palmaris arch formation, which is identical to baboons, and to the origin of the princeps pollicis artery, which is different from other primates (Fig.3).

\section{CONCLUSIONS}

In short, the arteries of the forearm and hand of Cebus are identical to other primates (humans, chimpanzees and baboons), however, the palmaris arch, which is only one in Cebus and baboons, and princeps pollicis artery, which is originated from palmaris arch, are the main differences found for the arterial model between Cebus and other primates. 
AVERSI-FERREIRA, T. A. Descripción anatómica comparativa de las arterias del antebrazo y de la mano del Cebus libidinosus. Int. J. Morphol., 27(1):219-226, 2009.

RESUMEN: Los datos recientes justifican la inserción de Cebus en los estudios sobre la evolución y el comportamiento en relación con la especie humana ya que, investigaciones sobre su comportamiento, memoria, uso de herramientas y índice encefálico han demostrado que los chimpancés y Cebus son similares en estos aspectos. Por otra parte, estudios anatómicos comparados de los Cebus y chimpancés sobre los datos anatómicos corroboran estos hechos sobre la convergencia evolutiva asociada a los músculos, nervios y vasos de los miembros torácicos, pero la anatomía de las arterias del antebrazo y mano no se ha investigado. En el antebrazo y mano de los Cebus las arterias son idénticas a otros primates estudiados aquí, pero el arco palmar es sólo uno en los Cebus y babuinos y, la arteria principal del pulgar se origina a partir del arco palmar. Éstas son las principales diferencias encontradas para el modelo arterial de Cebus y de otros primates a excepción de los babuinos. El modelo general de la vascularización del Cebus es idéntico al de otros primates y seres humanos, pero las características particulares de algunas arterias son diferentes a éstos últimos y más similares a babuinos.

PALABRAS CLAVE: Anatomía; Mono capuchino; Cebus; Arterias; Antebrazo.

\section{REFERENCES}

Antinucci, F. \& Visalberghi, E. Tool use in Cebus apella: A case study. Int. J. Primatol., 7:351-63, 1986.

Auricchio, P. Primatas do Brasil. São Paulo, Terra Brasilis, 1995.

Aversi-Ferreira, T. A.; Lima-e-Silva, M. S.; Pereira-dePaula, J.; Gouvêa-e-Silva, L. F. \& Penha-Silva, N. Anatomia comparativa dos nervos do braço de Cebus apella. Descrição do músculo dorsoepitroclear. Acta Sci., 27:291-6, 2005a.

Aversi-Ferreira, T. A.; Aversi-Ferreira R. A. G. M. F.; Silva, Z.; Gouvêa-e-Silva, L. F. \& Penha-Silva, N. Estudo anatômico de músculos profundos do antebraço de Cebus apella (Linnaeus, 1766). Acta Sci., 27:297-301, 2005b.

Aversi-Ferreira, T. A.; Pereira-de-Paula, J.; Lima-e-Silva, M. S.; Prado, Y. C. L. \& Silva, Z. Estudo anatômico das artérias do ombro de Cebus libidinosus (RYLANDS, 2000; PRIMATES - CEBIDAE). Ciên. Anim. Bras., 8:272-84, 2007a.

Aversi-Ferreira, T. A.; Pereira-de-Paula, J.; Prado, Y. C. L.; Lima-e-Silva, M. S. \& Mata, J. R. Anatomy of the shoulder and arm muscles of Cebus libidinosus. Braz. J. Morphol. Sci., 24:3-14, $2007 \mathrm{~b}$.

Aversi-Ferreira, T. A.; Vieira, L. G.; Pires, R. M.; Silva, Z. $\&$ Penha-Silva, N. Estudo comparativo entre os músculos flexores superficiais do antebraço de macaco Cebus e do homen. Biosci. J., 22:139-44, 2006.
Breseida, D. R. \& Ottoni, E. B. Observational learning in the manipulation of a problem-box by tufted capuchin monkeys (Cebus apella). Rev etol., 3:3-13, 2001.

Chevalier-Skolnikoff, S. Spontaneous tool use and sensorimotor intelligence in Cebus compared with other monkeys and apes. Behav Brain Sci., 12:561627, 1989.

Costello, M. B. \& Fragaszy, D. M. Prehension in Cebus and Saimiri: Grip type and hand preference. Am. J. Primatol., 15:235-45, 1988.

Ferreira, J. R. \& Prada, I. L. S. Nomenclatura proposta para denominar as artérias da base do encéfalo do macaco-prego (Cebus apella L., 1766). Acta Sci., 23:63543, 2001.

Garber, P. A. Foraging strategies among living primates. Annu. Rev. Anthropol., 16:339-64, 1987.

Gray, H. Anatomy of Human Body. Philadelphia, Lea \& Febiger, 1918.

Lopes, R. J. Gênio da selva. Sciam. Brasil, 27:25-32, 2004.

Lima, B.; Fiorani, M. \& Gattass, R. Modulation by context of a scene in monkey anterior inferotemporal cortex during a saccadic eye movement task. An. Acad. Bras. Ciênc., 75:71-6, 2003.

Manners-Smith, T. The Limb Arteries of Primates: Part I. J. Anat. Physiol., 44:271-302, 1910a. 
Manners-Smith, T. The Limb Arteries of Primates. $J$. Anat. Physiol., 45:23-64, $1910 \mathrm{~b}$.

Mendes, F. D. C.; Martins, L. B. R.; Pereira, J. A. \& Marquezan, R. F. Fishing with a Bait: A Note on Behavioural Flexibility in Cebus apella. Folia Primatol., 71:350-2, 2000.

Moore, L. K. \& Dalley, A. F. O membro superior. In: Anatomia orientada para a clínica. $2^{\mathrm{a}}$ ed. Rio de Janeiro, Guanabara Koogan, 2001. pp.591-725.

Neto, E. G. B. S. \& Ferreira, J. R. Estudo anatômico da origem e distribuição dos ramos corticais das artérias cerebrais caudais do encéfalo do macacoprego (Cebus apella L., 1766). Acta Sci., 24:63946, 2002.

Oliveira, A. S.; Ferreira, J. R. \& Blumenschein, A. R. Estudo anatômico do modelo arterial de vasos responsáveis pelo aporte sanguíneo da glândula submandibular de primatas neotropicais (Cebus apella, Linnaeus, 1766). Acta Sci., 22:573-9, 2000.

O'Rahilly, R. Anatomia humana básica. Rio de Janeiro, Interamericana, 1985.

Ottoni, E. B.; Resende, B. D.; Mannu, M.; Aquino, C. M. C.; Sestini, A. E. \& Izar, P. Tool use, social structure, and information transfer in capuchin monkeys. Adv. Ethol., 36:234, 2001.

Paiva, M. J. A. F. D. Causas e Conseqüências da encefalização nos hominídeos. Departamento de Antropologia da Universidade de Coimbra. http:// nautilus.fis.uc.pt/wwwantr/areas/paleontologia/ e $\mathrm{n} \mathrm{c}$ e f a l / $\mathrm{t}$ e $\mathrm{x}$ t o s / h t m l/ causas\%20e\%20consequencias.htm, 1998.

Perondi, M. A. M.; Izar, P. \& Ottoni, E. B. Uso de ferramentas por macacos-prego (Cebus apella) em condições de semi-cativeiro: Observações preliminares. Anais Etol., 13:416, 1995.

Resende, B. D. \& Ottoni, E. B. Brincadeira e aprendizagem do uso de ferramentas em macacosprego (Cebus apella). Estud. Psicol., 7:173-80, 2002.

Resende, M. C.; Tavares, M. C. H. \& Tomaz, C. Ontogenetic dissociation between habit learning and recognition memory in capuchin monkeys (Cebus apella). Neurobiol. Learn Mem., 79:19-24, 2003.
Rylands, A. B.; Schneider, H.; Langguth, A.; Mittermeier, R. A.; Groves, C. P. \& Rodriguez-Luna, E. An assessment of the diversity of new world primates. Neotrop. Primat., 8:61-93, 2000.

Santini, M. E. L. Observações sobre o comportamento social Cebus apella em cativeiro. In: A primatologia no Brasil. Congresso Brasileiro de Primatologia. Brasilia, Sociedade Brasileira de Primatología, 1983. pp.65-9.

Silva, R. A. \& Ferreira, J. R. Estudo das artérias cerebelares do macaco-prego. Considerações sobre a nomenclatura (Cebus apella L.; 1766). Braz. J. Vet. Res. Anim. Sci., 39:296-300, 2002.

Silva, R. A. \& Ferreira, J. R. Estudo anatômico das artérias cerebelares inferiores rostrais de macacoprego (Cebus apella L., 1766). Primates - Cebidae. Publ. Avul. Inst. Pau Brasil, 7:13-24, 2003.

Spence, A. P. Sistema muscular. In: Anatomia Humana básica. $2^{\mathrm{a}}$. ed. São Paulo, Manole, 1991.

Swindler, D. R. \& Wood, C. D. Superior member. In: An atlas of primate gross anatomy. Washington, University of Washington Press, 1973.

Tavares, M. C. H. \& Tomaz, C. A. B. Working memory in capuchin monkeys (Cebus apella). Behav. Brain Res., 131:131-7, 2002.

Testut, L. \& Latarjet, A. Músculos do membro superior. In: Tratado de Anatomia Humana. Barcelona, Salvat, 1959.

Toth, N.; Schick, K. D.; Savage-Rumbaugh, E. S.; Sevcik, R. A. \& Rumbaugh, D. M. Pan the toolmaker: Investigations into the stone-tool-making and tool-using capabilities of a bonobo (Pan paniscus). J. Archaeol. Sci., 20:81-91, 1993.

Visalberghi, E.; Fragaszy, D. M. \& Savage-Rumbaugh, S. Comprehension of causal relations in a tool-using task by chimpanzees (Pan troglodytes), bonobos (Pan paniscus), orangutans (Pongo pygmaeus), and capuchins (Cebus apella). J. Comp. Psychol., 109:52-60, 1995.

Waga, I. C.; Dacier, A. K.; Pinha, P. S. \& Tavares, M. C. H. Spontaneous tool use by wild capuchin monkeys (Cebus libidinosus) in the Cerrado. Folia Primatol., 77:337-44, 2006. 
Westergaard, G. C. \& Fragaszy, D. M. The manufacture and use of tools by capuchin monkeys (Cebus apella). J. Comp. Psychol., 101:159-68, 1987.

\section{Correspondence to:}

Dr. Tales Alexandre Aversi-Ferreira.

Universidade Federal de Goiás - Campus Catalão

Departamento de Enfermagem

Goiás

BRAZIL

Tel : $+55643441-1500$

Fax: +55 64 3441-1515

Email: aversiferreira@hotmail.com

Received: 08-07-2008

Accepted: 08-10-2008 